US strategy

\title{
President Reagan opts for anti-missile defence
}

Washington

PRESIDENT Reagan's call last week for the development of technology that could "intercept and destroy strategic ballistic missiles before they reached our soil or that of our allies" has been received with taunts of "Star Wars"' and "Buck Rogers" from Congress and expressions of scepticism and concern from many scientists. The chief concern is that space-based defence would trigger an arms race in space, endangering the surveillance and early warning satellites that provide a stabilizing force in the superpowers' nuclear stand-off.

The President has also provoked a certain ribaldry. Some have called him Ronald Ray Gun. The New York Post carried a headline "Star Wars to Zap Red Nukes",

Reagan acknowledged in his speech last week that this technology may be decades away. He ordered an intensive research and development programme as a top priority.

Congressional leaders questioned where the money was to come from and why it was not mentioned in the President's budget request.

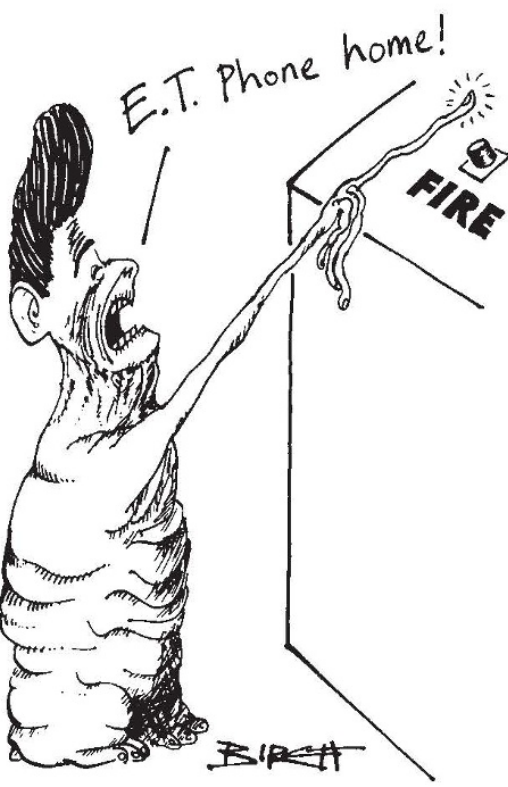

Reagan specifically called upon the scientific community "who gave us nuclear weapons to turn their great talents to the cause of mankind and world peace: to give us the means of rendering these nuclear weapons impotent and obsolete". Thirteen scientists, including Hans Bethe, Frank Press, Burton Richter, Edward Teller, Harold Agnew, Charles Townes and Victor Weisskopf, were invited to the White House for a briefing on the proposal before Reagan's speech.

On the telephone, Hans Bethe expressed several doubts about the proposal. "Suppose we got such a system and the Russians did not. Surely they would do all they could to frustrate that system". Bethe said he was "worried" that it could lead to "Star Wars" that would threaten the stabilizing role of observation satellites. Others, including Victor Weisskopf, have said that if either side were to deploy an effective defence, the other side would be left totally vulnerable to a nuclear attack and would feel compelled to knock out the defence which could itself trigger a nuclear war.

Bethe also expressed doubts that a missile defence system could ever be practicable. "I cannot exclude that something like this could be workable, and it is better than previous proposals, but $I$ have no idea how to do it. It would take many, many years"' in any event, he said.

"If you want a defensive system that's useful against nuclear weapons, it has to be 90 per cent effective or better', he added. "It's not like anti-aircraft weapons in the last war. But many people in our present government don't see that difference."

Asked why he and the other scientists were invited to the White House briefing, Bethe replied, "That's the mystery. It's not clear why the idea was announced at this time, why at such an early stage of research." Bethe said the briefing was "very thin" and that the scientists "were allowed a couple of questions which were not answered very well".

The Soviet news agency Tass was quick to claim that the proposed system would violate the US-Soviet antiballistic-missile treaty. Caspar Weinberger, the US Secretary of Defense, conceded that the treaty might have to be amended if the system were ever deployed, but he defended the right of the United States to carry out research and development under the terms of the treaty.

The idea of space-based missile defence was articulated last year in a study by the Heritage Foundation, a conservative think-tank. The study, called the "High Frontier", directed by Lt General Daniel Graham, US Army (Ret.), called for the abandonment of the "bankrupt and basically immoral precepts of Mutual Assured Destruction". The study claimed that a first-generation "Global Ballistic Missile Defense" could be deployed in five to six years at a cost of $\$ 10,000-15,000$ million. This system would use selfpropelled interceptors armed with conventional explosives and based on a series of satellites. The study also advocated in creasing research on lasers and particlebeams, the second-generation systems, by $\$ 100$ million per year. Stephen Budiansky
Williamsburg summit

\section{Agenda calls for collaboration}

THE Western economic summit meeting arranged for Williamsburg, Virginia, in May can look forward to some relief from its usual sombre agenda of the problems of the world economy - an upbeat paper on the value of science and technology as an instrument of economic improvement.

The document, Technology, Growth and Employment (published in Britain as Cmnd 8818, HMSO, £3.55), has been prepared by a group of officials set up after the summit meeting at Versailles in June 1982 , at least in part in response to President François Mitterrand's advocacy of the importance of technology. The chairman of the group was M. Jacques Attali, special counsellor of the President of France.

Two themes stand out in the report the importance of basic research and the need for international collaboration. The report also includes a list of topics on which international collaboration is thought to have particular potential which reads a little like a delicate blend of projects governments have been unable successfully to manage on their own account and others they would like to get their teeth into.

Thus controlled thermonuclear fusion and photosynthesis are listed as deserving energy projects, while aquaculture, highspeed trains and biotechnology are all commended as fields in which collaboration could be fruitful. Conspicuous by its absence is most governments' present interest - information technology (but robots win a mention).

Some of the recommendations in the working group's report are unlikely, however, to be fully welcomed except as platitudes by the governments represented at Williamsburg - Canada, France, Italy, Japan, the United Kingdom, the United States, West Germany and the European Community. Thus the report urges that governments should support only basic research and long-term "high-risk" development projects, leaving more immediate projects to the private sector. The report also urges the importance of commercial competition as a means to the rational division of labour between states, asking in particular that governments should open their markets for public-sector purchases to all comers.

While much of the document is general (and familiar), each of the projects on which collaboration is commended is spelled out in such detail (together with the names of the countries that would be responsible) but in such modest terms that only the most stony summit will fail to agree with the proposals. The result should be a noticeable increase in the volume and scope of the funds available for international collaboration. 